\title{
FLOHOF 2007: an overview of the mesoscale meteorological field campaign at Hofsjökull, Central Iceland
}

\author{
Joachim Reuder • Markus Ablinger • Hálfdán Ágústsson • Pascal Brisset • Sveinn Brynjólfsson • \\ Markus Garhammer · Tómas Jóhannesson • Marius O. Jonassen • Rafael Kühnel • Stephan Lämmlein • \\ Tor de Lange $\cdot$ Christian Lindenberg $\cdot$ Sylvie Malardel $\cdot$ Stephanie Mayer • Martin Müller • \\ Haraldur Ólafsson · Ólafur Rögnvaldsson • Wolfgang Schäper · Thomas Spengler • Günther Zängl • \\ Joseph Egger
}

Received: 31 July 2009/Accepted: 22 December 2010/Published online: 21 January 2011

(C) The Author(s) 2011. This article is published with open access at Springerlink.com

\begin{abstract}
The FLOHOF field campaign took place in the period July 21 to August 24, 2007 on and in the surroundings of Hofsjökull glacier in Central Iceland. During the campaign, 18 automatic weather stations (AWS) recording temperature, humidity, wind speed, wind direction, pressure, and precipitation were deployed on and around the glacier. In addition, atmospheric soundings were performed $\mathrm{N}$ and $\mathrm{S}$ of Hofsjökull by a tethered balloon, pilot balloons, and two unmanned aerial systems (UAS). An energy balance station, consisting of a net radiometer and an eddy correlation flux measurement station, has also been installed. This paper describes the experimental setup of the campaign and presents first results of the data analysis with respect to transience of mountain-induced gravity waves, the extension of katabatic
\end{abstract}

J. Reuder $(\bowtie)$ - M. O. Jonassen · T. de Lange · S. Mayer ·

H. Ólafsson · Ó. Rögnvaldsson · T. Spengler

Geophysical Institute, University of Bergen,

Allegaten 70, 5007 Bergen, Norway

e-mail: joachim.reuder@gfi.uib.no

M. Ablinger · M. Garhammer · R. Kühnel · W. Schäper ·

G. Zängl · J. Egger

Meteorological Institute, University of Munich,

Theresienstrasse 37, 80333 München, Germany

H. Ágústsson

University of Iceland, Orkugarður v/Grensásveg,

Reykjavik, Iceland

H. Ágústsson · Ó. Rögnvaldsson

Institute for Meteorological Research, Orkugarður v/Grensásveg,

Reykjavik, Iceland

P. Brisset

Ecole Nationale de l'Aviation Civile, 7 avenue Edouard Belin,

31055 Toulouse, France winds into the surrounding of the glacier, the occurrence of katabatic microfronts, and report on novel approaches to probe the vertical structure of the atmospheric boundary layer by UAS. The observed pressure perturbations related to transient gravity wave activity due to changing inflow conditions were between -2 and $2 \mathrm{hPa}$ in general, with positive values upstream and negative values downstream. Differential heating of the glacier and its surrounding is triggering daytime katabatic flow from the glacier into its surrounding. During the campaign, those katabatic winds typically reached out 4-7 km from the edge of the glacier. During late night in clear sky conditions, frontal-like microstructures have been observed frequently with typical repetition times in the order of 30-60 min indicating the interaction of large-scale synoptic and nighttime katabatic

\author{
S. Brynjólfsson · H. Ólafsson \\ University of Iceland, Bústaðavegi, Reykjavík, Iceland \\ S. Brynjólfsson · T. Jóhannesson · H. Ólafsson \\ Icelandic Meteorological Office, Bústaðavegi, \\ Reykjavík, Iceland \\ S. Lämmlein \\ Laboratory for Flow Measurements, University of Applied \\ Sciences Regensburg, Galgenbergstrasse 30, \\ 93053 Regensburg, Germany \\ C. Lindenberg · M. Müller \\ Martin Müller Engineering, Orleansstrasse 26a, \\ 31135 Hildesheim, Germany \\ S. Malardel \\ Meteo-France, ENM, 42 Avenue Gustave Coriolis, \\ 31057 Toulouse, Cedex, France
}


density flows close to the ground. The first research application of the newly developed small unmanned meteorological observer proved the applicability of the system for atmospheric boundary layer research by successfully profiling the atmosphere up to $3.5 \mathrm{~km}$ above ground.

\section{Introduction}

The campaign FLOHOF (Flow Over and around HOFsjökull) has been conducted in summer 2007 (July 21August 24) near and at the glaciated mountain Hofsjökull in Iceland. One central aspect to be addressed by the FLOHOF campaign was the observation of transience or in-stationarity of mountain-induced gravity waves. It is standard practice to consider mountain-induced gravity waves as quasi-stationary phenomena. There are, of course, good reasons for this point of view. These waves are excited by flows over and around the mountains which belong in most cases to systems of relatively large scale when compared with that of a mountain so that their timescale is fairly long. It is reasonable to assume that the gravity waves equilibrate long before this large scale flow undergoes substantial changes. On the other hand, transience is inevitably part of the observations of gravity waves over mountains. Any change in the ambient flow induces waves given stable stratification of the atmosphere. These waves may propagate out of the mountain region, but may as well contribute locally to changes of the quasistationary pattern. In most reported cases of gravity wave activity, stationarity is assumed to distill a reasonably coherent picture from the measurements. Nevertheless, there is also some information available on transience in gravity waves (Smith and Broad 2003; Smith et al. 2007). As of today, however, no field program has been conducted to look specifically at the transience of mountain waves. Typically, aircraft with sophisticated instrumentation is used to investigate mountain waves (Smith et al. 2007). Upper-level wave structures are derived from a few flight legs. This approach must almost be ruled out for transience investigations because reasonably long observational records are needed to capture transient effects. They have to include the passage of several synoptic systems over a mountain. The cost of collecting a sufficiently dense set of aircraft data over such a long time is prohibitive. Thus lowcost surface stations have to provide the backbone for a field program aiming at observing gravity wave transience. Gravity waves leave a trace in the surface pressure record and their transience is reflected there. This paper reports on the campaign FLOHOF to investigate gravity wave transience by relying mainly on surface observations. The mountain Hofsjökull in Iceland is almost completely covered by ice and its surface is quite smooth. Its shape is fairly circular and its diameter of around $30 \mathrm{~km}$ is large enough that motion of gravity waves over Hofsjökull should be detectable. There is, perhaps, no other mountain of this size in the world which is as ideally shaped as Hofsjökull for applications of linear theory.

A second scientific focus area was the investigation of the extension of katabatic glacier winds into the surrounding areas. As the air away from the glacier is warmed up on a sunny day, the air close to the surface of the glacier becomes relatively cold and dense and katabatic winds are generated. The existence of such winds at the edge of glaciers is known and their diurnal and seasonal cycle has been described for locations, such as the Hintereisferner in the Alps (Obleitner 1994). Extensive observations and modelling efforts have been carried out of katabatic winds over the Breiðamerkurjökull outlet from Vatnajökull glacier in SE-Iceland (Oerlemans et al. 1999; Parmhed et al. 2004; Söderberg and Parmhed 2006). The experiment showed the katabatic winds to be very persistent over the glacier outlet during summertime, with maximum wind speed typically at few tens of meters above the ground or even lower. For geographical reasons, the Breiðamerkurjökull experiment from 1996 could not be extended into the ice-free land. Consequently, the experiment did not provide detailed information on the destiny of the katabatic winds, once they had crossed the edge of the glacier. The only description of katabatic winds over ice-free land in Iceland in the international literature to the knowledge of the authors was made by Ágústsson et al. (2007) and such winds were shown to extend a distance of the order of $100 \mathrm{~km}$ and to be quite persistent in the south-Iceland lowlands. Numerical simulations showed the maximum wind speed to be located much higher above the ground than in the cases of katabatic winds over Breiðamerkurjökull. The FLOHOF campaign provided observations of glacial katabatic flows, not only over the glacier, but also down to more than $7 \mathrm{~km}$ away from its the edge. These observations will be described in Sect. 3.2 with emphasis on the diurnal variations and horizontal extent of the katabatic flows.

Another scientific question addressed by the campaign was the investigation of the surface energy balance of a lava surface and the corresponding diurnal development of the atmospheric boundary layer. Characteristic for the lava surface is its relatively low albedo and consequently high surface energy input by absorption of solar radiation. In addition, the porous ground is draining precipitation quite efficiently away from the surface layers and therefore minimizing latent heat fluxes and evaporative cooling of the ground. This creates enhanced local and regional surface temperature gradients between the glacier and its surrounding. 
Last, but not the least the FLOHOF campaign was the first environmental test for a newly developed atmospheric profiling system, the Small Unmanned Meteorological Observer (SUMO) (Reuder et al. 2009; Jonassen 2008). This system, based on a small and light-weight model airplane equipped with an autopilot system, is intended to be operated as recoverable radiosonde system, in particular for the investigation of the atmospheric boundary layer. The main intention for the use of the system in the future is the compilation of a high-resolution data set in space and time for the validation of fine-scale numerical simulations and the test and improvement of the boundary layer parameterization schemes used in those models.

\section{The FLOHOF field campaign}

The FLOHOF field campaign took place in the period July 21 to August 24, 2007 on and in the surroundings of Hofsjökull glacier in Central Iceland. The main camp of the experiment was located at Ingólfsskáli $\left(65.01^{\circ} \mathrm{N}\right.$, $18.89^{\circ} \mathrm{W}, 845 \mathrm{~m}$ a.s.l.), about $5 \mathrm{~km} \mathrm{~N}$ of the ice edge of the glacier (N3b in Fig. 1). Here, a cabin with accommodation capacity for around 20 people provided the basic infrastructure for the field experiment. During the campaign, 18 automatic weather stations (AWS) for the measurement of temperature $(T)$, humidity (rh), wind speed (vv), wind direction $(\mathrm{dd})$, pressure $(p)$, and precipitation $(P)$ were deployed on and around the glacier. In addition, atmospheric soundings were performed $\mathrm{N}$ and $\mathrm{S}$ of Hofsjökull by a tethered balloon, pilot balloons, and two measurement systems based on Unmanned Aerial Vehicles (UAV). An energy balance station, consisting of a net radiometer and an eddy correlation flux measurement station, was also installed at the main camp.

\subsection{Instrumentation}

\subsubsection{Automatic weather stations}

For measuring basic meteorological parameters, a total number of 18 AWS were placed over and around Hofsjökull, 12 stations of the Geophysical Institute, University of Bergen (GFI), 5 stations of the Meteorological Institute, University of Munich (MIM), and 2 stations of the Institute for Atmospheric and Climate Science, ETH Zurich (ETH). All stations were additionally supplied with an autonomous HOBO RG3 logging rain gauge. The GFI-stations are based on the meteorological measurement system by AADI. The stations have been equipped with the sensor types 3455 for temperature, 3445 for relative humidity, the cup anemometer type 2740 for wind speed and the wind vane type 3590 for wind direction. Five of the elevated stations were additionally equipped with the pressure sensor 2810. All GFI stations without AADI pressure sensor were supplied with an Opus 10 TPR autonomous logging pressure sensor.

The MIM stations use the Vaisala DPA21 pressure transducer. Temperature and relative humidity have been measured with a combined temperature-humidity sensor from Fischer (type 4314). Both sensors were mounted in a ventilated housing to protect them from direct radiation.
Fig. 1 Location of the measurement sites on and around Hofsjökull during the FLOHOF campaign. The dashed line indicates the approximate ice extension of the glacier. Black dots indicate the positions of the temporarily installed AWS, diamonds permanently operating meteorological stations in the surrounding. The gray triangles $\mathrm{N}$ and SW of Hofsjökull mark the positions of intense vertical profiling activities by a tethered balloons and the two unmanned aerial systems SUMO and KALI

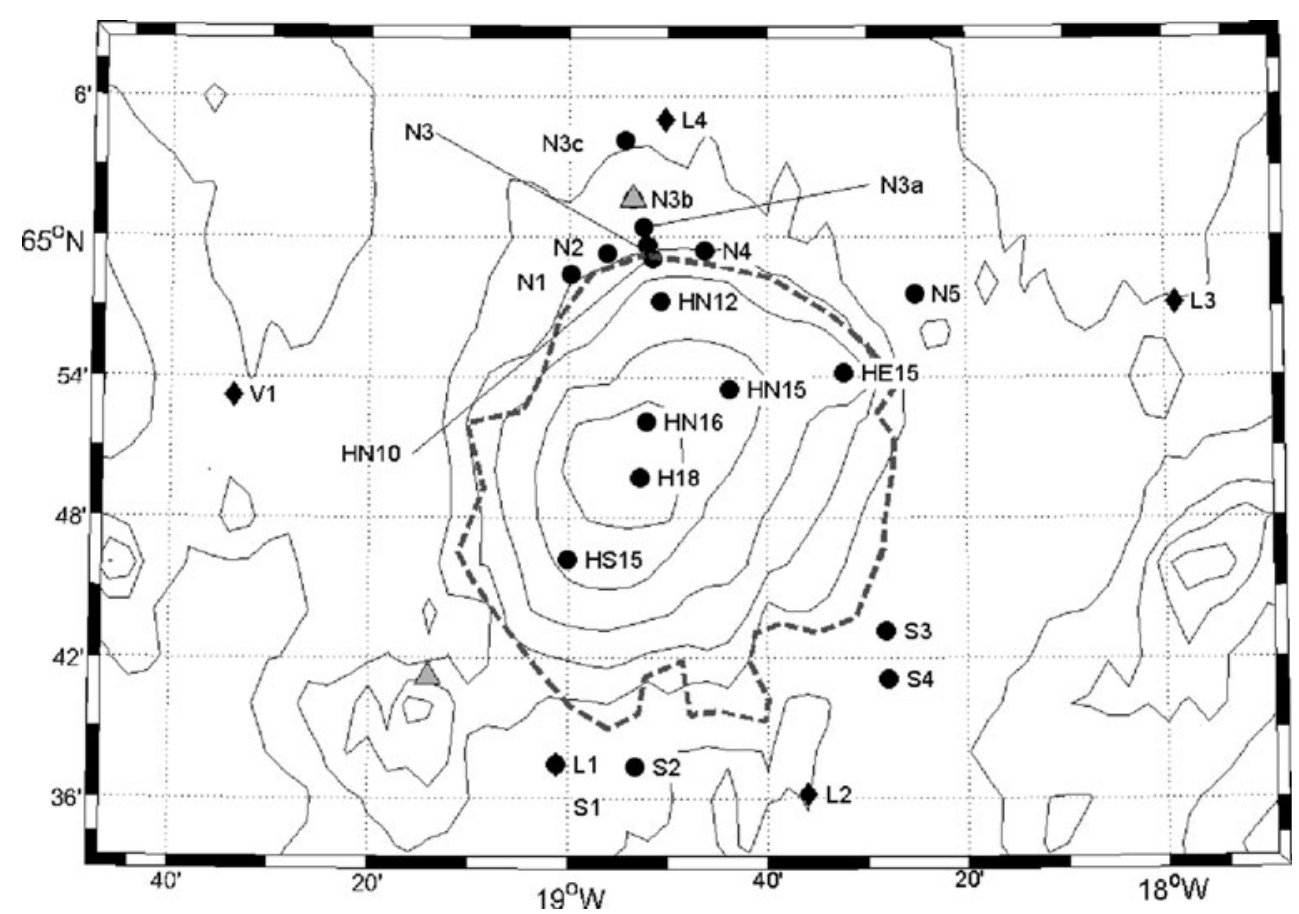


For wind speed measurements, the MIM stations used a cup vane anemometer (Siggelkow, type Lisa 6.001.1). Wind direction was measured via a wind vane (Siggelkow, type Rita Gray 6.002.1). The data have been logged on the Tefrilog from Friedrichs \& Co.

The ETH stations used two different pressure sensors. One the Vaisala PTB 100 analog barometer and the other the Druck RPT 410 barometric pressure sensor. Temperature was measured by the Campbell 107, relative humidity by a Vaisala HMP 45. Wind direction and speed were measured with the Vaisala Windcap Ultrasonic wind sensor WMT50. Further technical details on the stations and their sensors can be found in Kühnel (2008). For quality assurance reasons, the temperature, humidity and pressure sensors have been checked at least twice during the campaign by onsite comparison with an Assmann-psychrometer for temperature and humidity and a Vaisala PTB220TS microbarograph for pressure.

\subsubsection{Energy balance station}

All components of the surface energy balance, except ground heat flux, were measured directly at site N3b, close to the main camp at Ingólfsskáli cabin. The radiation balance has been determined by a Kipp\&Zonen CNR-1 net radiometer, separately measuring up- and downward directed fluxes of shortwave and longwave radiation with a time resolution of $10 \mathrm{~min}$. The eddy correlation system determines turbulent fluctuations of the three-dimensional wind vector, the sonic temperature, and the concentrations of water vapor and carbon dioxide with a temporal resolution of $20 \mathrm{~Hz}$. These data sets can be used to calculate directly the surface fluxes of momentum, sensible and latent heat and $\mathrm{CO}_{2}$. The used system consists of a combination of a sonic anemometer (Campbell CSAT-3) and an open path infrared absorption gas analyzer (LICOR 7500).

\subsubsection{Unmanned aerial systems}

For atmospheric boundary layer (ABL) profiling, two different UAS have been used during the FLOHOF campaign. The first, well-established system KALI (Egger et al. 2002, 2005), is based on an electrically powered model airplane of 1.3-m length and 2.1-m wingspan. It carries sensors for pressure, temperature and humidity and has a typical altitude range of about $2,000 \mathrm{~m}$ for atmospheric profiling. The system is remotely controlled and requires therefore continuous visual contact by the pilot in charge.

In contrast the second system, the Small Unmanned Meteorological Observer SUMO (Reuder et al. 2008, 2009; Jonassen 2008), has autonomous flight capabilities. The prototype of the system used during FLOHOF is based on the commercially available FunJet model construction kit by
Multiplex, a delta-wing pusher prop jet composed of the foam material EPP (expanded propylen). With its length of $75 \mathrm{~cm}$, its wingspan of $80 \mathrm{~cm}$ and an overall weight of $580 \mathrm{~g}$, SUMO can be seen as recoverable radiosonde for boundary layer monitoring. A lithium polymer (LiPo) battery pack with a capacity of $2,100 \mathrm{mAh}$ enables a flight endurance of around 20-30 min, and therefore profile ascents up to $3,500 \mathrm{~m}$ above ground. SUMO is equipped with the open-source autopilot system Paparazzi (Brisset et al. 2006; ENAC 2008). During the FLOHOF campaign, it has been equipped with a pressure-sensing element (SCP1000 by VTI Technologies) and a combined temperature and humidity sensor (DigiPicco I2C by IST). Although not carrying any kind of flow or wind sensor onboard, SUMO also can be used to derive atmospheric wind profiles. Flying SUMO in autonomous mode with constant pitch angle and throttle on a helical path results in nearly constant values of the true air speed. Headwind, therefore, will reduce the ground speed measured by the GPS system of the autopilot, tailwind will increase it. The average wind speed over one circle of the flight pattern can be determined from this ground speed difference, the average wind direction from the position of the corresponding ground speed minimum and maximum; for details, see Reuder et al. (2009).

\subsubsection{Tethered balloon}

The Atmospheric Instrumentation Research (AIR) tethersonde system was used for profile measurements of meteorological parameters in the ABL to altitudes of $1 \mathrm{~km}$. The sensor package (mod. TS-3A-SP) was attached to an aerodynamic (blimp) shaped balloon (mod. TS-1BR-0). The balloon is connected via a thin tetherline to an electric winch (mod. TS-3A), which allows the balloon including the sensor package to be raised and lowered through the boundary layer, typically with a vertical velocity in the order of $0.5 \mathrm{~m} / \mathrm{s}$. Meteorological parameters, including dry and wet bulb temperature, wind speed, wind direction, and pressure are transmitted every $10 \mathrm{~s}$ to an atmospheric data acquisition system at the ground.

\subsubsection{Balloon theodolites}

Four balloon theodolites (Warren Knight, Model No. 89 AFP) were used to determine profiles of wind speed and wind direction by releasing and tracking small helium-filled balloons. Each theodolite is equipped with encoders for azimuth and elevation angle. During the balloon ascent, the bearing angles are recorded every $10 \mathrm{~s}$ on a micro-pocket computer locally at each theodolite. With typical balloon ascent velocities of around $2 \mathrm{~m} / \mathrm{s}$ this results in a vertical resolution of the determined wind profiles in the order of $20 \mathrm{~m}$. After the ascent, the azimuth and elevation 
measurements of both theodolites are combined to derive wind profiles by the double pibal method (Thyer 1961; Schaefer and Doswell 1978).

\subsection{Measurement sites}

The 18 AWS on and around the glacier were distributed as a compromise between expected location of largest pressure perturbations with respect to the expected main wind directions and the accessibility of the sites. Large areas in the surroundings of Hofsjökull, especially in the western and eastern part, are nearly unaccessible even for larger 4 wheel drives due to deep river crossings and quicksand. On the glacier, large areas with cracks and crevasses had to be avoided for safety reasons. Figure 1 shows the final station setup consisting of a rather dense station network at the northern edge of the glacier and a few stations in the $S$. The seven stations on the glacier were arranged in a $\mathrm{Y}$-shape with legs oriented toward SW, N and E. The own AWS measurements close to Hofsjökull are complemented by four weather stations of the Icelandic National Power Company (Landsvirkjun) (labeled L1-L4) and one official meteorological station of the Icelandic Meteorological Office (Vedurstofa) at Hveravellir (V1). Eight stations, from the summit of the glacier $(\mathrm{H} 18)$ to N3c, around $10 \mathrm{~km}$ $\mathrm{N}$ of the ice edge, provide a dense $\mathrm{S}-\mathrm{N}$ transect for the investigation of katabatic downslope flow off the glacier and its penetration into the surrounding areas (Table 1).
The majority of the atmospheric soundings by pilot balloons, the tethered balloon system and the UAS were performed at the main camp at Ingólfsskáli (N3b). During a 3-day excursion to the $\mathrm{S}$ of Hofsjökull additional measurements with SUMO, KALI and the tethered balloon were carried out in parallel. Table 2 summarizes the atmospheric profile measurements taken by the different sounding systems during the FLOHOF campaign.

\subsection{Large-scale synoptic situation}

The general large-scale synoptic situation during the FLOHOF campaign was dominated by several low pressure systems, which passed with their centers mainly $S$ of Iceland. The first relevant system was developing $\mathrm{S}$ of Greenland on July, 22, moving eastwards and passing Iceland during July 25-26. Thereby, it left Iceland under the influence of $\mathrm{E}$ to $\mathrm{NE}$ winds. Cold and wet air masses reached Iceland on the back side of the cyclone. From then to July 30, the weather situation was governed by weak pressure gradients and calm NE winds. On July 30, another low-pressure system developed over Southern Greenland, which gradually intensified and influenced Central Iceland during its passage from July 31 to August 2. The wind speeds increased and turned from $\mathrm{W}$ to $\mathrm{S}$, transporting relatively warm and moist air masses toward the Hofsjökull region. On the backside of the system, winds turned to NE again. In the meanwhile the next intense cyclone evolved $\mathrm{S}$

Table 1 Location of the automatic weather stations (AWS) specifically operated during the FLOHOF campaign

\begin{tabular}{|c|c|c|c|c|c|}
\hline Name & Latitude deg $\mathrm{N}$ & Longitude deg E & Altitude (m) & Site description (distance to glacier edge) & Surface \\
\hline N1 & 64.953 & 18.996 & 847 & Flat gravel field $(300 \mathrm{~m})$ & Gravel, rocks and water \\
\hline $\mathrm{N} 2$ & 64.968 & 18.936 & 894 & On top of a small gravel ridge $(300 \mathrm{~m})$ & Gravel and rocks \\
\hline N3 & 64.974 & 18.868 & 880 & Gravel field $(10 \mathrm{~m})$ & Gravel, rocks and water \\
\hline $\mathrm{N} 3 \mathrm{a}$ & 64.987 & 18.875 & 865 & Lava field $(2 \mathrm{~km})$ & Lava \\
\hline $\mathrm{N} 3 \mathrm{~b}$ & 65.007 & 18.892 & 845 & Lava field $(5 \mathrm{~km})$ & Lava, sparse vegetation \\
\hline $\mathrm{N} 3 \mathrm{c}$ & 65.049 & 18.906 & 809 & Gravel field $(10 \mathrm{~km})$ & Gravel \\
\hline N4 & 64.970 & 18.772 & 954 & On top of a gravel moraine $(500 \mathrm{~m})$ & Gravel and rocks \\
\hline N5 & 64.939 & 18.419 & 807 & Gravel field (7 km) & Gravel \\
\hline HN10 & 64.965 & 18.860 & 996 & In the sloping area of the glacier & Bare, dirty ice \\
\hline HN12 & 64.934 & 18.845 & 1,175 & Snow field in a small depression of the ablation area & Wet snow \\
\hline HN15 & 64.871 & 18.730 & 1,497 & Plateau in the accumulation area & Snow \\
\hline HN16 & 64.848 & 18.870 & 1,603 & Northward facing slope in the accumulation area & Snow \\
\hline H18 & 64.809 & 18.881 & 1,777 & Plateau at the summit of the glacier & Snow \\
\hline HE15 & 64.883 & 18.538 & 1,458 & Summit of Miklafjell at the eastern ridge of the glacier & Snow \\
\hline HS15 & 64.750 & 19.001 & 1,486 & Southward facing slope in the accumulation area & Snow \\
\hline S1 & 64.613 & 18.888 & 702 & Flat gravel field $(5 \mathrm{~km})$ & Gravel and rocks \\
\hline $\mathrm{S} 2$ & 64.603 & 18.888 & 636 & Flat gravel field (4 km) & Gravel and rocks \\
\hline S3 & 64.699 & 18.469 & 629 & Flat tundra field $(3 \mathrm{~km})$ & Low vegetation \\
\hline S4 & 64.665 & 18.465 & 620 & Flat gravel field (7 km) & Gravel and rocks \\
\hline
\end{tabular}


Table 2 Overview of meteorological soundings during FLOHOF

\begin{tabular}{|c|c|c|c|c|c|c|c|c|}
\hline Day & Pos. & $\mathrm{m}$ a.s.l. & Lat & Lon & $\begin{array}{l}\text { Number of } \\
\text { KALI }\end{array}$ & $\begin{array}{l}\text { Number of } \\
\text { PILOT }\end{array}$ & $\begin{array}{l}\text { Number of } \\
\text { TETH }\end{array}$ & $\begin{array}{l}\text { Number of } \\
\text { SUMO }\end{array}$ \\
\hline 29.07 .2007 & $\mathrm{~N} 3 \mathrm{~b}$ & 840 & 65.01 & 18.89 & - & 14 & - & - \\
\hline 30.07 .2007 & $\mathrm{~N} 3 \mathrm{~b}$ & 840 & 65.01 & 18.89 & 7 & 21 & - & - \\
\hline 31.07 .2007 & $\mathrm{~N} 3 \mathrm{~b}$ & 840 & 65.01 & 18.89 & - & 1 & - & - \\
\hline 01.08.2007 & $\mathrm{N} 3 \mathrm{~b}$ & 840 & 65.01 & 18.89 & 4 & 6 & - & - \\
\hline 05.08.2007 & $\mathrm{N} 3 \mathrm{~b}$ & 840 & 65.01 & 18.89 & 3 & 5 & - & - \\
\hline 06.08.2007 & $\mathrm{N} 3 \mathrm{~b}$ & 840 & 65.01 & 18.89 & 3 & 4 & - & - \\
\hline 07.08.2007 & $\mathrm{N} 3 \mathrm{~b}$ & 840 & 65.01 & 18.89 & 8 & 9 & - & - \\
\hline 08.08.2007 & $\mathrm{N} 3 \mathrm{~b}$ & 840 & 65.01 & 18.89 & 5 & 9 & - & - \\
\hline 09.08.2007 & $\mathrm{N} 3 \mathrm{~b}$ & 840 & 65.01 & 18.89 & 6 & 6 & - & - \\
\hline 10.08 .2007 & $\mathrm{~N} 3 \mathrm{~b}$ & 840 & 65.01 & 18.89 & 2 & 2 & - & - \\
\hline 12.08 .2007 & $\mathrm{~N} 3 \mathrm{~b}$ & 840 & 65.01 & 18.89 & 2 & 4 & - & - \\
\hline 12.08 .2007 & Hver & 605 & 64.87 & 19.56 & 3 & - & - & - \\
\hline 13.08.2007 & $\mathrm{N} 3 \mathrm{~b}$ & 840 & 65.01 & 18.89 & 4 & 4 & - & - \\
\hline 13.08.2007 & Ker1 & 773 & 64.67 & 19.23 & 5 & - & 7 & 8 \\
\hline 14.08 .2007 & $\mathrm{~N} 3 \mathrm{~b}$ & 840 & 65.01 & 18.89 & 6 & 7 & - & - \\
\hline 14.08 .2007 & Ker2 & 676 & 64.69 & 19.29 & 3 & - & - & 4 \\
\hline 15.08 .2007 & $\mathrm{~N} 3 \mathrm{~b}$ & 840 & 65.01 & 18.89 & 3 & 4 & - & 1 \\
\hline 16.08 .2007 & $\mathrm{~N} 3 \mathrm{~b}$ & 840 & 65.01 & 18.89 & - & - & - & 2 \\
\hline 17.08 .2007 & $\mathrm{~N} 3 \mathrm{~b}$ & 840 & 65.01 & 18.89 & 5 & 5 & 6 & 6 \\
\hline 18.08.2007 & $\mathrm{N} 3 \mathrm{~b}$ & 840 & 65.01 & 18.89 & 5 & 8 & 4 & 9 \\
\hline 19.08 .2007 & $\mathrm{~N} 3 \mathrm{~b}$ & 840 & 65.01 & 18.89 & 6 & 5 & - & - \\
\hline 21.08 .2007 & $\mathrm{~N} 3 \mathrm{~b}$ & 840 & 65.01 & 18.89 & 2 & 2 & - & - \\
\hline Total & & & & & 82 & 116 & 17 & 30 \\
\hline
\end{tabular}

\section{First measurement results}

The following section will present first results based on the recent status of evaluation and interpretation of the comprehensive data set obtained during the FLOHOF field campaign.

\subsection{Pressure perturbations}

The pressure measurements at different stations were performed with different sampling intervals. Stations equipped with the OPUS pressure sensors measured every minute. Most of the AWS with integrated pressure sensors collected data in 2-min intervals, while for the stations in the S of Hofsjökull a sampling interval of five minutes was chosen because of the remote placement and the corresponding limited data storage capacity. For further evaluation, the whole dataset was converted to one minute resolution by linear interpolation. For the derivation of the relevant short-term pressure perturbations, the measured pressure time series at the different stations have to be corrected for measurement altitude and filtered for the removal of synoptic scale pressure variations. Because most of the stations were placed higher than $800 \mathrm{~m}$ above sea level, pressure was not reduced to sea level. Instead, the 
Table 3 Overview of meteorological situation during FLOHOF
$G$ integrated global irradiance, $\mathrm{Q}_{S}$ integrated radiation balance, $\mathrm{Q}_{H}$ integrated sensible heat flux, $P$ daily precipitation sum at the sites $\mathrm{N} 3 \mathrm{a}$ and $\mathrm{N} 3 \mathrm{c}$

\begin{tabular}{|c|c|c|c|c|c|c|}
\hline Day & Short weather summary & $\begin{array}{l}\mathrm{G} \\
{\left[\mathrm{MJ} \mathrm{m}^{-2}\right]}\end{array}$ & $\begin{array}{l}\mathrm{Q}_{S} \\
{\left[\mathrm{MJ} \mathrm{m}^{-2}\right]}\end{array}$ & $\begin{array}{l}\mathrm{Q}_{H} \\
{\left[\mathrm{MJ} \mathrm{m}^{-2}\right]}\end{array}$ & $\begin{array}{l}\mathrm{P}^{(N 3 a)} \\
(\mathrm{mm})\end{array}$ & $\begin{array}{l}\mathrm{P}^{(N 3 c)} \\
(\mathrm{mm})\end{array}$ \\
\hline 24.07 & Partly cloudy & - & - & - & 0 & 0 \\
\hline 25.07 & Partly cloudy & 18.0 & 9.9 & - & 0.6 & 0 \\
\hline 26.07 & Partly cloudy & 13.3 & 8.6 & - & 3.2 & 5.6 \\
\hline 27.07 & Overcast, some rain & 9.0 & 6.9 & - & 6.4 & 0.6 \\
\hline 28.07 & Mostly overcast, rain & 10.5 & 8.4 & - & 9.8 & 10.6 \\
\hline 29.07 & Sunny, few cu clouds & 20.9 & 13.5 & 3.6 & 1.0 & 1.0 \\
\hline 30.07 & Mostly overcast & 10.5 & 7.4 & 2.2 & 0.2 & 0 \\
\hline 31.07 & Overcast, rain & 7.2 & 6.0 & 1.3 & 11.8 & 7.6 \\
\hline 01.08 & m: Overcast, a: partly cloudy & 13.4 & 9.2 & 3.9 & 1.0 & 1.0 \\
\hline 02.08 & m: Fog, drizzle, a: partly cloudy & 15.6 & 9.0 & - & 0.8 & 0.2 \\
\hline 03.08 & Overcast, rain and snow & 4.9 & 3.2 & - & 5.4 & 7.6 \\
\hline 04.08 & Overcast, rain and snow & 3.0 & 2.5 & - & 4.2 & 1.8 \\
\hline 05.08 & m: Overcast, drizzle, a: partly cloudy & 12.9 & 8.1 & - & 0.4 & 1.0 \\
\hline 06.08 & Partly cloudy, a: showers & 16.8 & 8.0 & 2.4 & 0.6 & 0.4 \\
\hline 07.08 & Cloudy & 13.0 & 6.9 & 2.9 & 0 & 0 \\
\hline 08.08 & Partly cloudy & 16.2 & 8.9 & 4.3 & 0 & 0 \\
\hline 09.08 & Cloudy & 10.4 & 6.5 & 2.0 & 1.2 & 1.0 \\
\hline 10.08 & Mostly overcast, rain and fog & 8.2 & 6.3 & - & 7.6 & 3.8 \\
\hline 11.08 & Overcast, drizzle and fog & 4.3 & 3.5 & - & 2.2 & 1.2 \\
\hline 12.08 & Mostly overcast, drizzle and fog & 10.9 & 8.2 & - & 1.2 & 1.4 \\
\hline 13.08 & Cloudy, few light showers & 10.3 & 7.3 & - & 0.8 & 0.4 \\
\hline 14.08 & Partially cloudy & 14.1 & 8.5 & 5.3 & 0 & 0 \\
\hline 15.08 & Partially cloudy, few light showers & 13.1 & 8.1 & - & 0.2 & 0.2 \\
\hline 16.08 & Overcast, few light showers & 8.3 & 5.3 & - & 0.8 & 0.4 \\
\hline 17.08 & Cloudy, a: light showers & 9.7 & 5.2 & 2.2 & 0.6 & 0 \\
\hline 18.08 & Cloudy & 12.6 & 6.6 & 2.1 & 0 & 0 \\
\hline 19.08 & Partially cloudy, a: showers & 12.0 & 5.4 & 2.7 & 3.0 & 0 \\
\hline 20.08 & m: Sunny, a: partially cloudy & 16.3 & 10.1 & - & 0.2 & 0.2 \\
\hline 21.08 & Overcast, rain & 5.2 & 1.7 & - & 2.4 & 7.8 \\
\hline
\end{tabular}

direction. Two of these periods, one for SE flow and one for $\mathrm{N}$ flow are presented exemplary in the following.

Figure 3 presents the pressure disturbance profile for the period August 7-11, characterized by southerly synoptic flow below $5 \mathrm{~m} / \mathrm{s}$. The resulting pressure disturbance shows a strong upstream maximum at the stations HS15 and $\mathrm{H} 18$ of around $+1 \mathrm{hPa}$. The disturbance is decreasing to the $\mathrm{S}$, but still positive at stations $\mathrm{S} 1$ with $0.3 \mathrm{hPa}$. The decline in the $\mathrm{N}$ is much steeper than in the $\mathrm{S}$, dropping to $-0.7 \mathrm{hPa}$ at station $\mathrm{HN} 12$. An interesting feature is the local maximum created by the stations HN10, N3, and N3a close to the edge of the glacier. The overall value of the disturbance is with $-0.2 \mathrm{hPa}$ at $\mathrm{HN} 10$ and $\mathrm{N} 3$ still negative, but approximately $0.5 \mathrm{hPa}$ higher than at the surrounding stations. The standard deviation of the pressure disturbances varies little between 0.05 and $0.07 \mathrm{hPa}$ for all stations except $\mathrm{N} 3 \mathrm{a}$, where it increases to $0.19 \mathrm{hPa}$.

Figure 4 shows the pressure disturbance profile for large scale northerly flow in the period 15-16 of August. The 

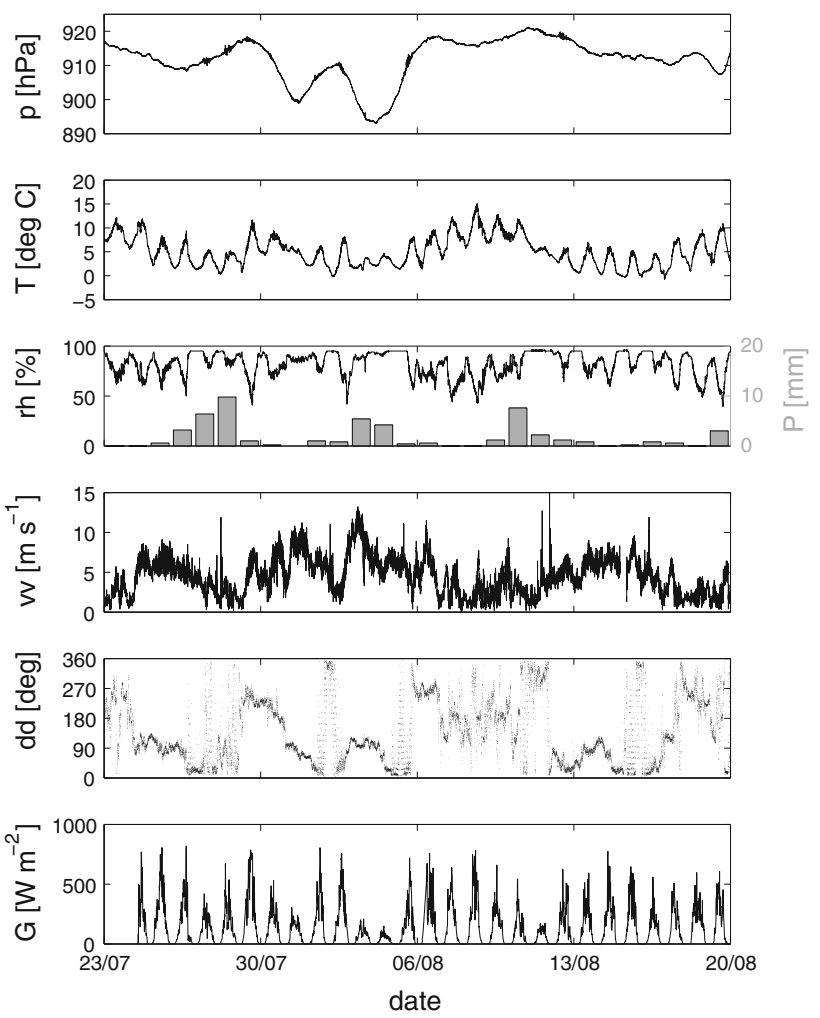

Fig. 2 Time series of the meteorological key parameters pressure, temperature, relative humidity and precipitation, wind speed, wind direction, and global solar irradiance during the FLOHOF campaign at the main camp at Ingólfsskáli cottage, site N3b. Owing to a failure of the HOBO rain gauge at $\mathrm{N} 3 \mathrm{~b}$ the precipitation measurements of site $\mathrm{N} 3 \mathrm{a}$, about $3 \mathrm{~km}$ to the $\mathrm{S}$, are presented

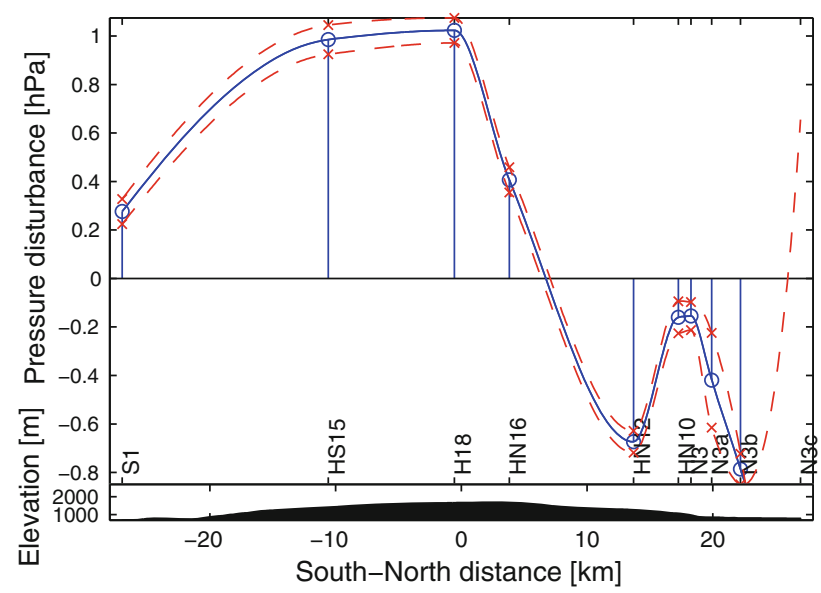

Fig. 3 Mean pressure disturbance for the period August 7-10 with large-scale southerly flow. The lower part of the plot shows the relief of Hofsjökull with markers for the positions of the stations along the $\mathrm{S}-\mathrm{N}$ axis. The solid line shows the mean pressure disturbance. The dashed lines show the standard deviations. The explicit values for the mean pressure disturbance and standard deviations at the stations are marked with circles and crosses. The values between the stations have been interpolated

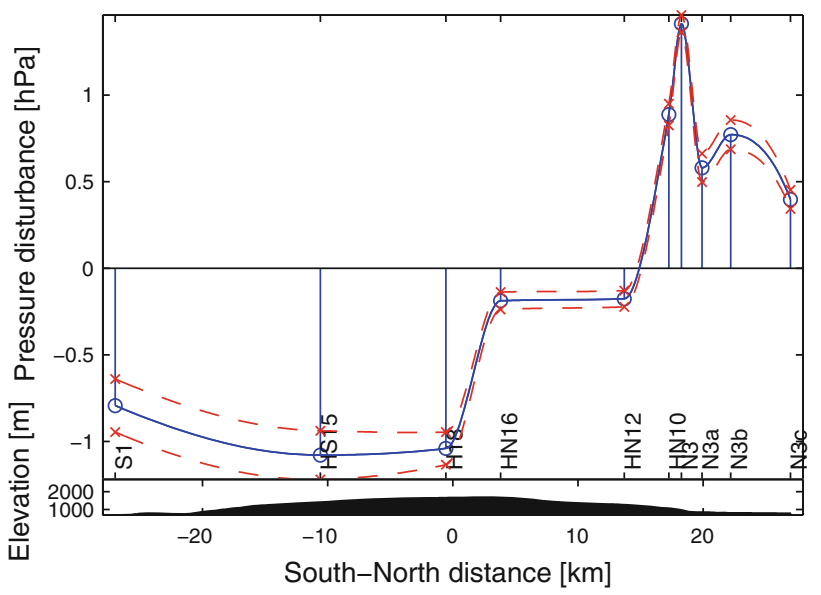

Fig. 4 Mean pressure disturbance for the period August 15-16 with large-scale northerly flow. The lower part of the plot shows the relief of Hofsjökull with markers for the positions of the stations along the $\mathrm{S}-\mathrm{N}$ axis. The solid line shows the mean pressure disturbance. The dashed lines show the standard deviations. The explicit values for the mean pressure disturbance and standard deviations at the stations are marked with circles and crosses. The values between the stations have been interpolated

average wind speed for this episode of around $5 \mathrm{~m} / \mathrm{s}$ was slightly higher than for the previous case. The pressure perturbation shows again positive values upstream, now in the $\mathrm{N}$ and negative values downstream in the $\mathrm{S}$. The absolute maximum lies hereby at station $\mathrm{N} 3$ with $+1.4 \mathrm{hPa}$. A second smaller maximum of $+0.8 \mathrm{hPa}$ is observed at station $\mathrm{N} 3 \mathrm{~b}$. This maximum is broader than that at station $\mathrm{N} 2$ and only $0.2 \mathrm{hPa}$ greater than the neighboring values. In the $\mathrm{S}$ of $\mathrm{N} 3$, the perturbation drops to $-0.2 \mathrm{hPa}$ at the stations $\mathrm{HN} 12$ and HN16. The decrease is not as smooth as in the case from 5 August. There is a second drop from station HN16 to H18 of $-0.9 \mathrm{hPa}$. The disturbances of H18 and HS15 are around $-1 \mathrm{hPa}$. At station $\mathrm{S} 1$, the perturbation is $-0.8 \mathrm{hPa}$. The standard deviation of the disturbances is in the $\mathrm{S}$ approximately $0.15 \mathrm{hPa}$. In the $\mathrm{N}$, including stations HN16 and $\mathrm{HN} 12$, it takes values between 0.05 and $0.1 \mathrm{hPa}$. As seen from Figs. 3 and 4, the standard deviation of the pressure observations is quite small. There is not much gravity wave activity for approximately constant mean wind. It is mainly the slow change in the mean wind which induces the changes of the surface pressure. A more comprehensive analysis of the data shows that this statement is true for the whole FLOHOF period at least for stations surrounding Hofsjökull.

\subsection{Katabatic winds}

Observations of winds and temperature from the top of the glacier and from the stations N3, N3a, N3b and N3c allow for an investigation of the horizontal extent of downslope winds and their diurnal variation. The above-mentioned 
stations form a line to the north from the northern edge of Hofsjökull glacier. N3 is situated at the edge of the glacier, while the subsequent stations $\mathrm{N} 3 \mathrm{a}, \mathrm{N} 3 \mathrm{~b}$ and $\mathrm{N} 3 \mathrm{c}$ are located in a distance of $1.5,3.7$ and $8.3 \mathrm{~km}$ from the edge of the glacier. Observations from the stations HN10 and HN12, which are both located on the glacier, could unfortunately not be used in this context due to problems with the wind measurements. As there are no useful profiles of temperature or winds close to the glacier or above it, one is restricted to surface observations when characterizing the local flow. A primary criteria for detecting katabatic flow is the absence of any significant large-scale winds, represented by the winds at the top of the glacier, and a secondary criteria is that the wind blows away from the glacier along the N3 to N3c section. An upstream direction is defined in such a way that $\mathrm{N} 3$ (at the edge of the glacier) is furthest upstream, and N3c is furthest downstream. The flow is considered to be katabatic when the wind direction at a given station and at all the upstream stations is between $150^{\circ}$ and $210^{\circ}$ and the wind speed at the top of the glacier at both stations $\mathrm{H} 18$ and H15 must be $<5 \mathrm{~m} / \mathrm{s}$. At that low wind speeds, the atmospheric flow at Hofsjökull is definitely blocked and in case of southerly synoptic winds, there is a wake at the northern edge of the glacier. The dataset fulfilling these criteria is scanned manually to exclude a handful of cases, where there is significant synoptic-scale circulation not represented by the winds observed at the top of Hofsjökull. The above criteria are quite strict and they do most likely exclude several cases of katabatic flow. The dataset is also restricted by the fact that there must be observations from every single one

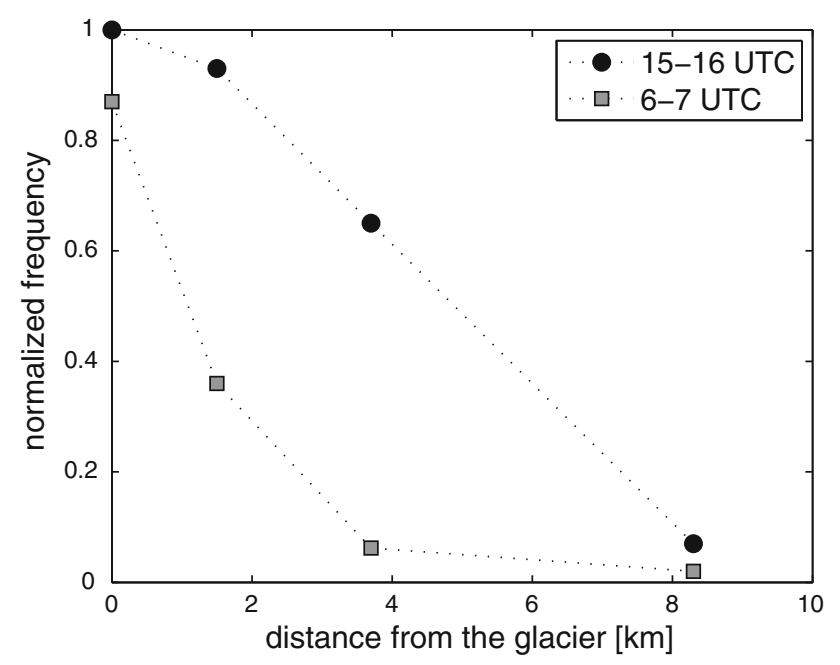

Fig. 5 The frequency of katabatic winds at stations N3, N3a $(1.5 \mathrm{~km}), \mathrm{N} 3 \mathrm{~b}(3.7 \mathrm{~km})$ and $\mathrm{N} 3 \mathrm{c}(8.3 \mathrm{~km})$ between 6 and 7 UTC in the morning and between 15 and 16 UTC in the afternoon. The frequency is normalized to the frequency in the afternoon at the edge of the glacier (143 cases) of the previously mentioned stations at the same time. The time resolution of the data is $2 \mathrm{~min}$.

Figure 5 shows the number of observations of katabatic flow at each weather station in the afternoon between 15 and 16 UTC and in the early morning between 6 and 7 UTC. As expected, the katabatic flow is more frequent in the afternoon, but at the edge of the glacier, the difference between the two times of the day is rather small. The afternoon katabatic winds do on the other hand extend further away from the glacier. At a distance of $1.5 \mathrm{~km}$ from the glacier (N3a), the early morning katabatic flow has faded out in about $60 \%$ of the cases, while in the afternoon a similar rate of fade out $(60 \%)$ is reached at a distance close to $6 \mathrm{~km}$ from the glacier (between N3b and N3c). At this distance, there is a rapid drop in frequencies of katabatic winds and at $8.3 \mathrm{~km}(\mathrm{~N} 3 \mathrm{c})$ they have disappeared in more than $90 \%$ of the cases.

The mean wind speed in the cases shown in Fig. 5 is given in Fig. 6. Between 15 and 16 UTC, the average wind speed is about $6 \mathrm{~m} / \mathrm{s}$ at the edge of the glacier, while in the late night, the corresponding values are below $4 \mathrm{~m} / \mathrm{s}$. In the afternoon, the mean wind speed is down to about $50 \%$ of its ice edge value about $4 \mathrm{~km}$ away from the glacier, while in the night, the mean winds are down to about $50 \%$ of the ice edge value at only about $1 \mathrm{~km}$ away from the glacier.

The solar heating of the ground leading to a temperature gradient between the glacier and its surroundings gives a considerable diurnal variation in the extent and magnitude of the katabatic winds eminating from Hofsjökull Glacier, similar in magnitude as observed in the Austrian Alps by Obleitner (1994). A typical maximum extent of the katabatic winds is $4-7-\mathrm{km}$ away from the glacier. This is an order of magnitude smaller than the night-time katabatic

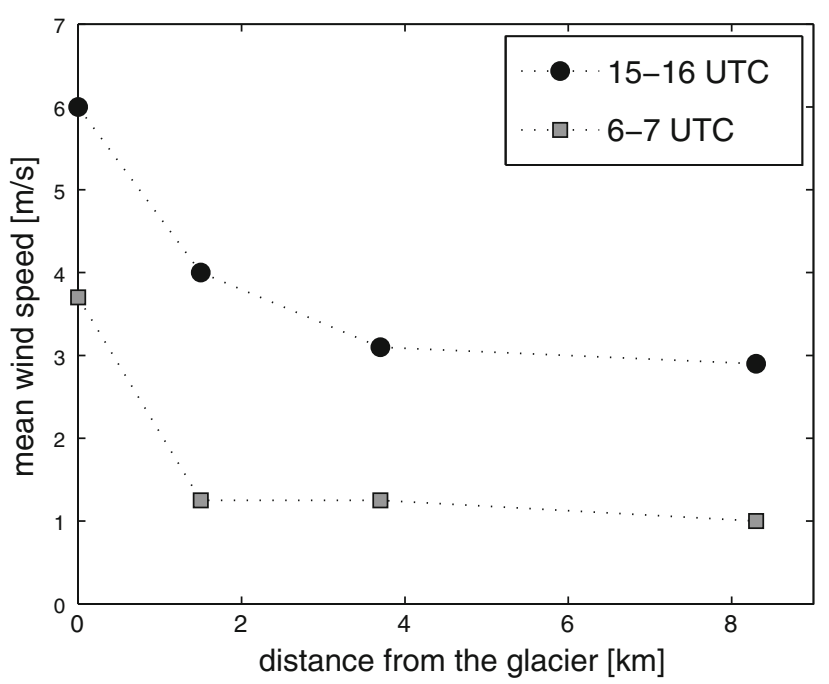

Fig. 6 Average wind speed of the katabatic flow shown in Fig. 5 as function of the distance from the glacier edge 
winds described in Ágústsson et al. (2007), although the maximum surface wind speeds are similar. The limited extension of the katabatic flow is of course an inevitable consequence of the solar heating of the ground, leading to a quick erosion of the cold surface flow. Unlike the nocturnal katabatic winds which are driven by radiative cooling, the solar heating generates the horizontal temperature gradients leading to the downslope flow observed here, but it also destroys them.

The persistence of the katabatic winds during daytime in the summer suggests that an area of roughly the size of Hofsjökull itself, surrounding the glacier is under the influence of katabatic winds from the glacier. This may indeed have a large impact on the summer climate of the region and consequently also on growing conditions for vegetation in the 'new' land that appears as the glacier retreats. The glacier-generated katabatic winds as described here may thus have a larger impact on the vegetation than the winds described in Ágústsson et al. (2007), although the latter extend to much greater distances from the glacier.
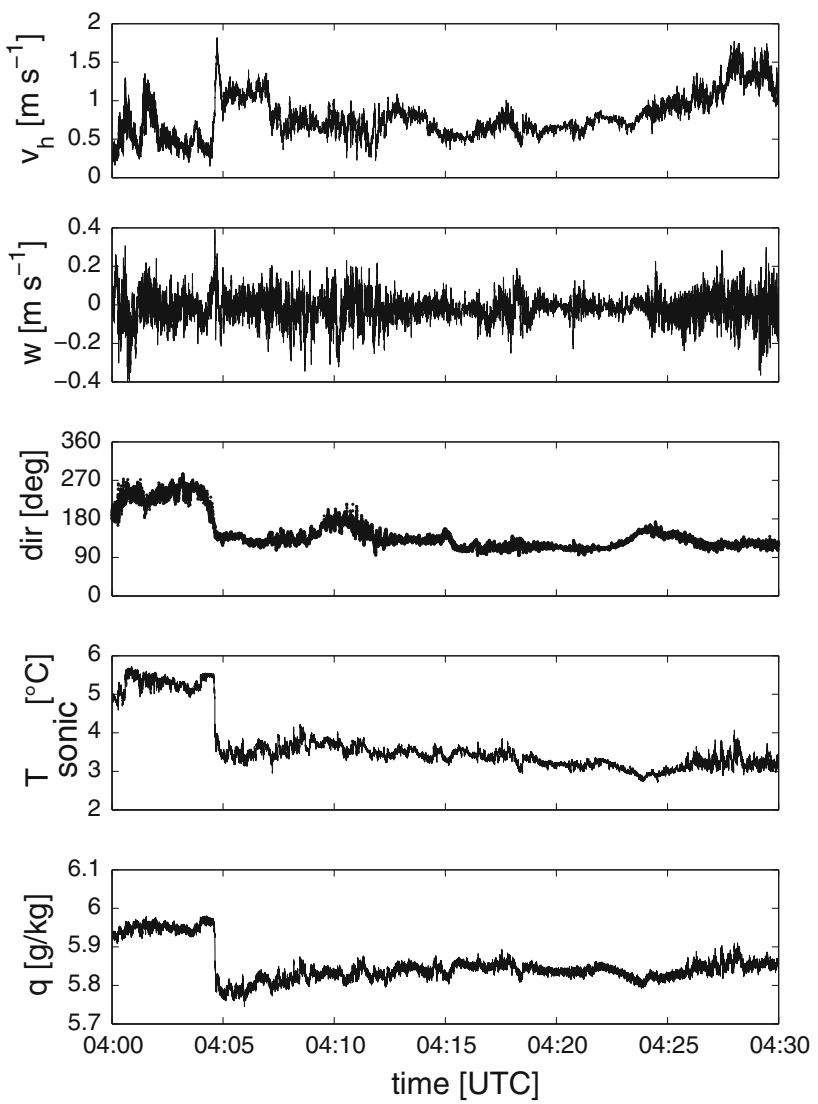

Fig. 7 Time series of the $20 \mathrm{~Hz}$ turbulence data set for half an hour early in the morning of August 19, 2007. The figure presents (from top to bottom) horizontal wind speed, vertical wind speed, wind direction, sonic temperature, and specific humidity

\subsection{Katabatic microfronts}

The installation of the eddy covariance system with a 20-Hz sampling frequency at the main site N3b allows for a more detailed analysis of fine scale atmospheric structures in the surface flow. During clear nights with weak synoptic winds, a frontal type phenomenon has been frequently observed at the site N3b during late night and early morning, typically in the time interval between 2 and 5 UTC. Figure 7 shows as an example one of these events at around 4:05 UTC in the morning of August 19, 2007. Starting with low winds of around $0.5 \mathrm{~m} / \mathrm{s}$ the wind speed increases sharply within few seconds to close to $2 \mathrm{~m} / \mathrm{s}$. At the same time, the vertical velocity undergoes a distinct sinus-like negative-positive cycle, indicating the passage of a vertical vortex. Applying Taylor's hypothesis, the length scale of the corresponding eddy should be in the

Table 4 Overview of SUMO soundings during FLOHOF

\begin{tabular}{llllcl}
\hline ID & $\begin{array}{l}\text { Date } \\
\text { (local time) }\end{array}$ & $\begin{array}{l}\text { Start time } \\
\text { (UTC) }\end{array}$ & $\begin{array}{l}\text { End time } \\
\text { (UTC) }\end{array}$ & $\begin{array}{l}\text { Max height } \\
\text { (m agl) }\end{array}$ & Pos. \\
\hline 1 & 13.08 .2007 & $11: 03$ & $11: 36$ & 432 & Ker1 \\
2 & 13.08 .2007 & $12: 04$ & $12: 21$ & 1,615 & Ker1 \\
3 & 13.08 .2007 & $13: 11$ & $13: 28$ & 2,599 & Ker1 \\
4 & 13.08 .2007 & $13: 48$ & $14: 10$ & 1,858 & Ker1 \\
5 & 13.08 .2007 & $15: 01$ & $15: 23$ & 525 & Ker1 \\
6 & 13.08 .2007 & $15: 52$ & $16: 09$ & 432 & Ker1 \\
7 & 13.08 .2007 & $16: 38$ & $17: 04$ & 438 & Ker1 \\
8 & 13.08 .2007 & $17: 25$ & $17: 49$ & 3,479 & Ker1 \\
9 & 14.08 .2007 & $12: 47$ & $13: 09$ & 2,463 & Ker2 \\
10 & 14.08 .2007 & $13: 46$ & $14: 22$ & 2,571 & Ker2 \\
11 & 14.08 .2007 & $15: 46$ & $16: 02$ & 1,021 & Ker2 \\
12 & 14.08 .2007 & $16: 11$ & $16: 26$ & 828 & Ker2 \\
13 & 15.08 .2007 & $18: 50$ & $19: 03$ & 970 & N3b \\
14 & 16.08 .2007 & $20: 30$ & $20: 47$ & 982 & N3b \\
15 & 16.08 .2007 & $20: 49$ & $21: 12$ & 1,488 & N3b \\
16 & 17.08 .2007 & $09: 22$ & $09: 52$ & 484 & N3b \\
17 & 17.08 .2007 & $09: 57$ & $10: 19$ & 975 & N3b \\
18 & 17.08 .2007 & $11: 03$ & $11: 28$ & 2,395 & N3b \\
19 & 17.08 .2007 & $12: 09$ & $12: 32$ & 1,184 & N3b \\
21 & 17.08 .2007 & $15: 07$ & $15: 28$ & 1,541 & N3b \\
22 & 17.08 .2007 & $15: 34$ & $15: 58$ & 1,271 & N3b \\
23 & 18.08 .2007 & $08: 16$ & $08: 39$ & 3,034 & N3b \\
24 & 18.08 .2007 & $08: 53$ & $09: 14$ & 3,344 & N3b \\
25 & 18.08 .2007 & $10: 04$ & $10: 27$ & 3,321 & N3b \\
26 & 18.08 .2007 & $11: 27$ & $11: 49$ & 994 & N3 \\
27 & 18.08 .2007 & $11: 51$ & $12: 09$ & 2,036 & N3 \\
28 & 18.08 .2007 & $12: 11$ & $12: 26$ & 337 & N3 \\
29 & 18.08 .2007 & $15: 22$ & $15: 40$ & 1,505 & N3b \\
30 & 18.08 .2007 & $17: 44$ & $17: 56$ & 1,022 & N3b \\
31 & 18.08 .2007 & $17: 56$ & $18: 11$ & 2,567 & N3b \\
\hline & & & & &
\end{tabular}


order of $50-100 \mathrm{~m}$. Associated with the passage of this structure, a distinct change in wind direction is observed, in this case from SW to E. A sharp and nearly instantaneous decrease in temperature of typically $2 \mathrm{~K}$ and specific humidity in the order of several tenth of $\mathrm{g} / \mathrm{kg}$ indicates the advection of a markedly different air mass. The flow structure reveals typical signs of a density current. In combination with the topography around the measurement site, the observations indicate the effects of intermittent episodes of two different flow regimes. The first one corresponding to SW wind directions is associated with the large-scale synoptic flow from W that is slightly channeled parallel to the edge of the glacier. The second one represents the katabatic drainage flow from the glacier and the mountains along the valley floor. The typical repetition time of those katabatic microfronts is in between $30 \mathrm{~min}$ and $1 \mathrm{~h}$ and agrees well with theoretical estimations on the variation of katabatic flow with time from a simple model (e.g. Helmis and Papadopoulos 1996).

\subsection{SUMO profiles}

The FLOHOF field campaign was the first environmental application of the newly developed atmospheric profiling system SUMO (Reuder et al 2009; Jonassen 2008). During 6 days of the experiment, 30 atmospheric profiles up to 3,300 $\mathrm{m}$ above ground level were performed (see Table 4). The profiles have been taken at four different locations, two in the SW of Hofsjökull (Ker1, Ker2) and two in the N, at the main site $\mathrm{N} 3 \mathrm{~b}$ at Ingólfsskáli and directly at the edge of the glacier (N3).

Figure 8 shows as an example the temperature profiles taken during August 18, documenting the diurnal development of the atmospheric boundary layer and the lower parts of the free atmosphere up to ca. $3 \mathrm{~km}$ above ground.

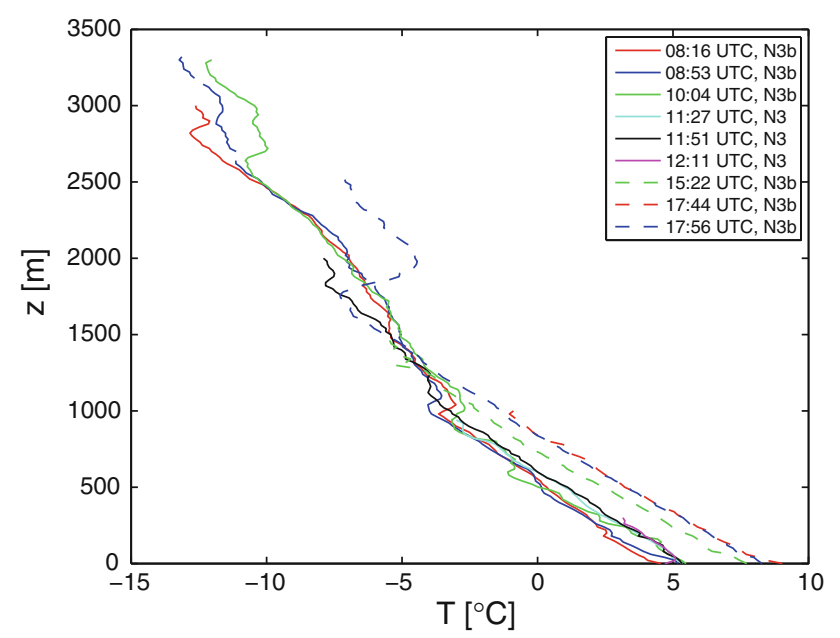

Fig. 8 SUMO temperature profiles taken on August 18 at the sites $\mathrm{N} 3 \mathrm{~b}$ and $\mathrm{N} 3$
At 8:00, about $3 \mathrm{~h}$ after sunrise, there is a well mixed layer in the lowest $200 \mathrm{~m}$, capped by a weak remainder of the nocturnal inversion. Above and up to an inversion at $1,000 \mathrm{~m}$ a neutral to slightly stable residual layer can be identified. The free atmosphere above is slightly stable stratified and shows the signature of a subsidence inversion at $2,800 \mathrm{~m}$. The profiles during the next hours document continuous warming from the ground and a corresponding increase in the mixed layer depth (around $500 \mathrm{~m}$ at 9:00 and $800 \mathrm{~m}$ at 10:00). Around 11:30, the boundary layer inversion of the previous day has been eroded, the mixed layer now extends to $1,100 \mathrm{~m}$. During the afternoon, the whole mixing layer/ABL is warmed by about $3 \mathrm{~K}$ and reaching a maximum depth of $1,300 \mathrm{~m}$, indicated by a weak temperature inversion and a corresponding slight reduction in humidity. The well-pronounced inversion around $1,800 \mathrm{~m}$ in the 18:00 ascent is not related to diurnal boundary layer development, but rather the signature of ongoing rapid subsidence related to the increasing influence of a high-pressure system. During the observation period, the altitude of this inversion above ground has decreased by around $1,000 \mathrm{~m}$ from $2,800 \mathrm{~m}$ at $8: 00$ and $2,600 \mathrm{~m}$ at $10: 00$ to the value of $1,800 \mathrm{~m}$ observed in the last ascent. The subsidence process is also confirmed by the 12:00 radiosounding of Keflavik (around $260 \mathrm{~km} \mathrm{SW}$ of Hofsjökull) which reports a strong inversion at $700 \mathrm{hPa}$, i.e. around $3 \mathrm{~km}$ above sea level or 2,200 $\mathrm{m}$ above the site of the SUMO measurements. Figure 9 presents the corresponding wind profiles for the same day. In the morning, there are weak winds below $700 \mathrm{~m}$. Above, the profiles show a continuous increase to values of around $10 \mathrm{~m} / \mathrm{s}$ above 2,000 $\mathrm{m}$. Consequently, the wind speed in the mixed layer during the day increases due to downward mixing of momentum associated with the mixed layer growth.

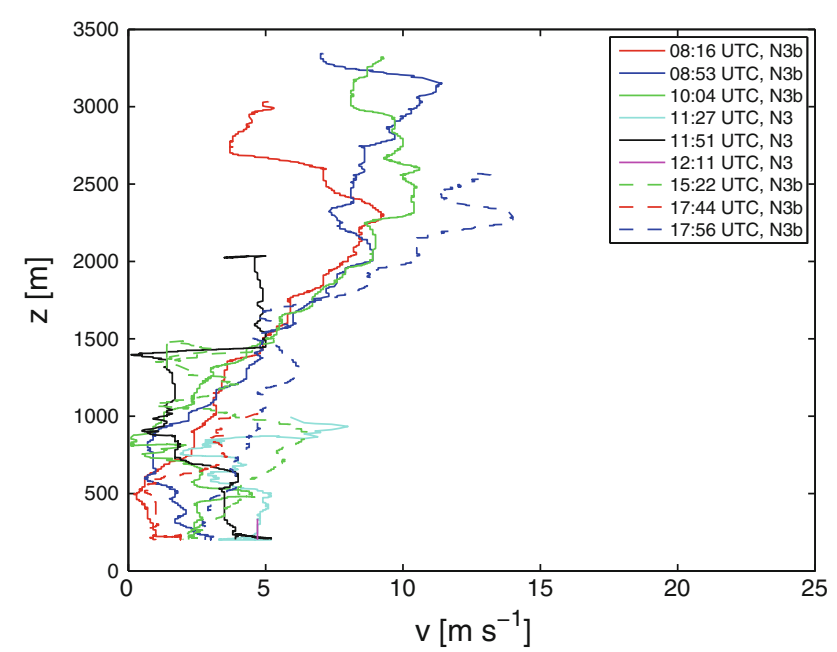

Fig. 9 SUMO wind speed profiles taken on 18 August at the sites $\mathrm{N} 3 \mathrm{~b}$ and $\mathrm{N} 3$ 
However, the wind speed remains below $5 \mathrm{~m} / \mathrm{s}$ up to $1,500 \mathrm{~m}$ above ground. Late in the afternoon, the layer above the fast descending subsidence inversion at around $1,700 \mathrm{~m}$ shows a marked increase in wind speed up to $15 \mathrm{~m} / \mathrm{s}$. The 30 atmospheric profiles gathered by the SUMO system during the 6 days have been the basis for an extensive boundary layer study during the campaign focusing on the validation of model parameterization schemes [Mayer et al. 2010 (this issue)]. Owing to the sensor-less wind determination method (Reuder et al. 2009), the SUMO system was not able to provide reliable wind data at altitudes below $200 \mathrm{~m}$ above ground. Therefore, those profile measurements were only of limited use for the investigations on the katabatic flow in the area.

\section{Summary and outlook}

During the FLOHOF campaign, a comprehensive atmospheric data set has been compiled which has been and will be subject to more detailed investigations (e.g. Egger 2009; Egger and Kühnel 2010; Mayer et al. 2010). Nevertheless, some important conclusions can already be drawn from the evaluations done so far:

- The observed pressure perturbations related to gravity wave activity were between -2 and $2 \mathrm{hPa}$ in general. They showed an opposite behavior on the northern and southern side of the mountain, depending on the wind direction, with positive values upstream and negative values downstream. A superimposed local maximum to this general behavior, most likely due to local orographic effects, seems to exist at the northern edge of the glacier; for more details, see Egger and Kühnel (2010) and Kühnel (2008).

- The solar heating of the ground, leading to a temperature gradient between the glacier and its surroundings gives a considerable diurnal variation in the extent and magnitude of the katabatic winds emanating from Hofsjökull Glacier, similar in magnitude as observed in the Austrian Alps by Obleitner (1994). In the afternoon, the mean speed of the katabatic winds is more than $6 \mathrm{~m} / \mathrm{s}$ at the edge of the glacier, but the winds decelerate rapidly and stop typically $4-7 \mathrm{~km}$ away from the glacier. The persistence of these winds during daytime in the summer suggests that an area of roughly the size of Hofsjökull itself, surrounding the glacier is under the influence of katabatic winds. This may indeed have a large impact on the summer climate of the region.

- During late night in clear sky conditions, frontal-like microstructures have been observed frequently with typical repetition times in the order of 30-60 min, indicating the interaction of large-scale synoptic and katabatic density flows close to the ground.

- The first research application of the newly developed Small Unmanned Meteorological Observer (SUMO) exceeded all expectations. The successful observation of meteorological profiles up to $3.5 \mathrm{~km}$ clearly proved the potential of the system to close the observational gap between meteorological masts and towers and radiosondes. One of the main future applications of SUMO will be its operation as recoverable radiosonde to collect high-resolution four-dimensional data sets for the validation of fine scale numerical simulations of the atmosphere. The results of the SUMO profiling with respect to model validation issues are presented in Mayer et al. (2010).

Acknowledgments The FLOHOF campaign was mainly funded by the German Research Foundation (DFG) under grant number EG 40/25-1, with supplement by the Geophysical Institute, University of Bergen. The authors would like to thank a lot of people and organizations on Iceland. Without their support and enthusiasm the campaign would have never been so successful. Hrafnhildur Hannesdóttir, Maria Edwardsdóttir, Einarpór Haraldsson, Kolbrún Vignisdóttir, Eydis Lilja Haraldsdottir, and Sigrún Tomasdóttir for assistance during the field work. Orkustofnun (Icelandic Energy Authorities), Oddur Sigurðsson and Bergur Einarsson for the provision of equipment and assistance, Porvaldur Steingrimsson for supply of snow mobiles and Pordur Hansen for assistance in transportation in really rough conditions. We are also greatful to Ferðafélag Skagfirðinga (Skagafjörður tourist club) and Landsvirkjun (The Icelandic Power Company) for the provision of accommodation and last, but not least to the Icelandic air traffic control for excellent and unbureaucratic collaboration on balloon and UAS operation. Many thanks to Veðurstofa (the Icelandic Meteorological Office) for logistic support, in particular the provision of accommodation at the station Hveravellir during the short campaign in the South. Last but not least thanks to Karl Schroff (ETH Zürich) and Hilbert Wendt (University of Munich) for technical assistance in preparation of the instrumentation for the campaign.

Open Access This article is distributed under the terms of the Creative Commons Attribution Noncommercial License which permits any noncommercial use, distribution, and reproduction in any medium, provided the original author(s) and source are credited.

\section{References}

Ágústsson H, Mira A, Cuxart J, Ólafsson H (2007) Observations and simulation of katabatic flows during a heatwave in Iceland. Meteorol Z 16(1):99-110

Brisset P, Drouin A, Gorraz M, Huard PS, Tyler J (2006) The Paparazzi solution. http://www.recherche.enac.fr/paparazzi/ papers_2006/mav06_paparazzi.pdf

Egger J (2009) Time varying flow over mountains: temperature perturbations at the surface. Meteorol Z 18(1):101-106

Egger J, Kühnel R (2010) Orographic gravity waves induced by variable mean winds: observations at Hofsjökull. Meteorol Z 19(1):101-113 
Egger J, Bajrachaya S, Heinrich R, Kolb P, Lämmlein S, Mech M, Reuder J, Schäper W, Shakya P, Wendt H (2002) Diurnal winds in the Himalayan Kali Gandaki valley. Part III: remotely piloted aircraft soundings. Mon Wea Rev 130:2042-2058

Egger J, Blacutt L, Ghezzi F, Heinrich R, Kolb P, Lämmlein S, Leeb M, Mayer S, Palenque E, Reuder J, Schäper W, Schween J, Torrez R, Zaratti F (2005) Diurnal circulation of the Bolivian Altiplano. Part I: observations. Mon Wea Rev 133:911-924

ENAC (2008) Paparazzi user's manual. http://paparazzi.enac.fr/ wiki_images/Users_manual.pdf

Helmis CG, Papadopoulos KH (1996) Some aspects of the variation with time of katabatic flow over a simple slope. Q J R Meteorol Soc 122:595-610

Jonassen M (2008) The Small Unmanned Meteorological Observer (SUMO)-characterization and test of a new measurement system for atmospheric boundary layer research. Master's thesis, Geophysical Institute, University of Bergen

Kühnel R (2008) Observations and results of the FLOHOF Field Campaign 2007. Master's thesis, Meteorological Institute, Ludwig-Maximilians-University, Munich, Germany

Mayer S, Sandvik A, Jonassen M, Reuder J (2010) Atmospheric profiling with the UAS SUMO: a new perspective for the evaluation of fine-scale atmospheric models. Meteorol Atmos Phys. doi:10.1007/s00703-010-0063-2, 12 pp

Obleitner F (1994) Climatological features of glacier and valley winds at the Hintereisferner (Ötztal Alps, Austria). Theor Appl Climatol 49(4):225-239

Oerlemans J, Björnsson H, Kuhn M, Obleitner F, Pálsson F, Smeets CJPP, Vugts HF, Wolde JD (1999) Glacio-meteorological investigations on Vatnajökull, Iceland, summer 1998: an overview. Bound Layer Meteorol 92:3-26

Parmhed O, Oerlemans J, Grisogono B (2004) Describing surface fluxes in katabatic flow on Breiðamerkurjökull, Iceland. Q J R Meteorol Soc 130:1137-1151

Reuder J, Brisset B, Jonassen M, Müller M, Mayer S (2008) Sumo: a Small Unmanned Meteorological Observer for atmospheric boundary layer research. Earth Environ Sci 1. doi:10.1088/17551307/1/1/012014, $10 \mathrm{pp}$

Reuder J, Brisset B, Jonassen M, Müller M, Mayer S (2009) The Small Unmanned Meteorological Observer SUMO: a new tool for atmospheric boundary layer research. Meteorol Z 18(2):141147

Schaefer JT, Doswell CA III (1978) The inherent position errors in double-theodolite pibal measurements. J Appl Meteorol 17:911-915

Smith RB, Doyle JD, Jiang Q, Smith SA (2007) Alpine gravity waves: Lessons from MAP regarding mountain wave generation and breaking. Q J R Meteorol Soc 133:917-936

Smith SA, Broad AS (2003) Horizontal and temporal variability of mountain waves over Mont Blanc. Q J R Meteorol Soc 129:2195-2216

Söderberg S, Parmhed O (2006) Numerical modelling of katabatic flow over a melting outflow glacier. Bound Layer Meteorol 120(3):509-534

Thyer N (1961) Double theodolite pibal evaluating by computer. J Appl Meteorol 1:66-68 